\title{
Morfoanatomi Daun Jambu Air (Syzygium samarangense) var. Demak Normal dan Terserang Hama Ulat
}

\section{Morfoanatomy Normal Leaf and Infected Pest Leaf of Water Guava (Syzygium samarangense) var. Demak}

\author{
Hadyani Millati Hanifa ${ }^{1}$, Sri Haryanti ${ }^{2} *$ \\ ${ }^{1}$ Program Studi Biologi, Departemen Biologi, Fakultas Sains dan Matematika, Universitas Diponegoro \\ ${ }^{2}$ Departemen Biologi, Fakultas Sains dan Matematika, Universitas Diponegoro \\ Jl. Prof. Soedarto, SH, Tembalang, Semarang \\ *Email : sharyanti87@yahoo.com
}

Diterima 27 Mei 2016/ Disetujui 12 Agustus 2016

\begin{abstract}
ABSTRAK
Jenis jambu air yang banyak ditanam yaitu Syzygium quaeum (jambu air kecil) dan Syzygium samarangense (jambu air besar). Jambu Citra yang berasal dari daerah Demak adalah yang paling diminati masyarakat, karena buahnya besar dan perawatan tanamannya mudah. Meskipun demikian keberadaan hama pengganggu tanaman tidak jarang dijumpai, sehingga menyerang daun dan buahnya. Akibat serangan hama produktivitas buah menurun, baik kualitas maupun kuantitasnya.. Tujuan penelitian ini adalah untuk mengamati perbedaan morfologi dan anatomi antara daun yang normal dengan daun yang terserang hama. Penelitian dilakukan pada bulan Desember 2013 dengan wawancara, observasi, studi pustaka dan praktik di laboratorium yaitu pembuatan preparat irisan melintang daun metode semipermanen dan replika. Pengamatan parameter daun normal dan yang terserang hama dilakukan secara deskriptif. Hasil penelitian menunjukkan bahwa morfologi dan anatomi daun jambu normal berbeda dengan yang terserang hama. Daun yang normal berbentuk lonjong dengan ujung meruncing tersusun oleh jaringan epidermis atas dan bawah, palisade dan spons parenkim serta berkas pengangkut. Daun yang terserang hama bentuknya ada yang tidak teratur, berkerut, helaian tidak rata, menggulung atau warna helaian kecoklatan atau hitam. Secara anatomis ada yang epidermisnya hilang/rusak, palisade rusak membentuk rongga-rongga, spons parenkim atau berkas pengangkut rusak atau helaiannya berlubang, sehingga mengurangi fungsi daun dalam proses fotosintesis.
\end{abstract}

Kata kunci : daun, normal, terserang hama, anatomi

\begin{abstract}
Types of guava which are widely planted is Syzygium quaeum (small water guava) and Syzygium samarangense (big water guava). Citra guava from Demak is the most interested guava in the community, because fruits are large and easy to maintain. Nevertheless the presence of pests are not rare found, so that attacks the leaves and fruits. Insect decreases quality and quantity of fruit productivity.. This study aims to observe the morphological and anatomical differences between normal leaf and infected leaf pests. The study was conducted in December 2013, through interviews, observation, library research and practice in laboratories, making preparations of cross-sectional leaf with semi-permanent method and replicas. Observation parameters of normal leaf and infected leaf pests was done descriptively. The results showed that the morphology and anatomy of normal leaf and infected leaf pests are different. The normal leaf has ovalshaped with a tapered tip composed by epidermis tissue, palisade and spongy parenchyma and vascular tissue. Infected leaf pests has irregular, wrinkled, uneven strands, curled leaf or brownish or black leaf blade color. Based on its anatomy, infected leaf pests has corrupted epidermis, damaged palisade in form of cavities, damaged spongy parenchyma, damaged vascular tissue or perforated leaf blade, so it reduces the leaf function in the photosynthesis process.
\end{abstract}

Keywords: leaf, normal, pest, anatomy 


\section{PENDAHULUAN}

Jambu air termasuk suku jambu-jambuan atau Myrtaceae yang berasal dari Asia Tenggara. Kayu buah jambu air yang keras dan berwarna kemerahan cukup baik sebagai bahan bangunan. Menurut Prihatman (2000), jambu air banyak sekali jenisnya. Jenis jambu air yang banyak ditanam yaitu Syzygium quaeum (jambu air kecil) dan Syzygium samarangense (jambu air besar). Bentuk daunnya bulat telur sampai lonjong atau elips. Warna daun yang muda merah, sedang yang tua hijau (Adieb ,2010). Mahkota bunganya terdiri dari empat helai. Bunganya berwarna putih kehijauan dan putih kemerahan, dan berbenang sari amat banyak berbentuk seperti paku (Hariyanto, 1992).

Menurut Setjo (2001) jaringan mesofil daun terdapat diantara epidermis atas dan bawah. Pada daun dikotil jaringan mesofilnya berdiferensiasi menjadi jaringan spons parenkim, palisade parenkim dan berkas pengangkut. Jaringan spons terdiri dari sel-sel berbentuk tidak teratur dengan dinding tipis dan mengandung sedikit kloroplas dengan ruang antar sel besar, sehingga memudahkan pertukaran gas. Jaringan palisade parenkim tersusun dari sel-sel bentuk silindris memanjang, selapis atau lebih rapat satu sama lain, mengandung banyak kloroplas yang didalamnya banyak klorofil berfungsi dalam menangkap cahaya untuk proses fotosintesis. Jaringan berkas pengangkut tersusun oleh xilem, floem serta sel pengiring dan parenkim. Fungsi xilem dalam jaringan pengangkut adalah mengangkut air dan zat hara dari tanah, sedang floem mengangkut hasil fotosintesis ke seluruh tubuh tumbuhan.

Hama adalah semua herbivora yang dapat merugikan tanaman yang dibudidayakan manusia secara ekonomis. Akibat serangan hama produktivitas tanaman menurun, baik kualitas maupun kuantitasnya, bahkan tidak jarang terjadi kegagalan panen Usaha kegiatan pengendalian hama, pengenalan terhadap jenis-jenis hama serta gejala kerusakan tanaman menjadi sangat penting agar tidak melakukan kesalahan dalam mengambil tindakan pengendalian (Djafarudin,2001).

Hama yang banyak menyerang tanaman jambu antara lain pengorok daun Liriomyza spp, Acrocercops syngramma Meyrick, ulat, Pestalotiopsis psidii dan serangga Helopeltis theobromae, serta lalat buah Dacus (Fabricus) dan Bactrocera (Macquart). Hama pengorok daun (Liriomyza spp) termasuk Ordo Diptera yang mempunyai 26 spesies. Ciri-ciri hama ini ukuran tubuhnya kecil dan adanya kemiripan antar spesies (Rauf, 1995). Serangan pada daun berupa tusukan di bagian permukaan atas daun . Bekas tusukan baik untuk makan atau peletakan telur menjadi bintik-bintik putih saat menetas larva pengorok menyerang bagian jaringan palisade. Daun tampak berbintik coklat akibat tusukan ovipositor betina saat menghisap cairan sel-sel daun dan meletakkan telur dalam jaringan daun. Kerusakan selanjutnya terlihat lubang-lubang dalam daun oleh larvanya menyebabkan daun berwarna merah kecoklatan (Tarumingkeng, 1994).

Hama Acrocercops syngramma adalah ulat pengorok daun yang polifag dan lebih menyukai daun muda. Akibat serangan ulat ini terjadi liang yang berliku-liku pada daun yang dimakan. Ulat membuat lubang keluar pada epidermis daun setelah 2 minggu memakan mesofil daun sehingga lapisan epidermis mengelupas, ulat keluar dan membuat rongga baru. Selanjutnya bagian daun yang dimakan akan kering dan gugur (Deptan, 1995). Telur diletakkan pada permukaan daun muda, jika menetas warna putih, sehingga daun tampak bengkok-bengkok.

Ulat kipat termasuk Ordo Lepidoptera, serangga dewasa berupa ngengat aktif pada malam hari. Serangan ulat ini relatif sama dengan ulat bulu yaitu daun tanaman akan habis bahkan gundul. Serangan awal ulat kecil dimulai dari bagian bawah daun muda dan serangan lanjutan ulat besar menyerang daun yang tua (Anonymous, 2011). Mengenal kerusakan pada tanaman yang disebabkan oleh berbagai pengganggu akan sangat membantu dalam diagnosis dan histopatologis. Deskripsi dan analisis struktur anatomi dan hasil diagnosisnya dapat menentukan keberhasilan suatu pengelolaan penyakit tanaman. Upaya menentukan serangan yang dilakukan oleh hama jenis tertentu adalah secara identifikasi. Identifikasi dapat dilakukan dengan melihat gejala serangan. Serangan yang disebabkan oleh hama seperti serangga akan meninggalkan gejala kerusakan yang khas pada tanaman tersebut. Menurut Djafarudin (2001), gejala kerusakan adalah setiap perubahan pertanaman yang mengarah pada pengurangan hasil dan kualitas dari yang diharapkan akibat serangan hama. Mengenal kerusakan tanaman yang disebabkan oleh berbagai pengganggu sangat membantu dalam diagnosis dan histofitopatologis. Hasil diagnosis dan analisis akan menentukan keberhasilan suatu pengelolaan penyakit tanaman. Kegagalan suatu diagnosis menyebabkan kegagalan tahap pengendalian. 
Meskipun parasit yang menyebabkan penyakit pada tanaman umumnya menyerang bagian reproduktif permukaan tanaman yang diserangnya, namun juga menyerang bagian vegetatifnya di dalam jaringan yang tidak tampak dari luar (Triharso, 2004).

Dari uraian di atas maka perlu dilakukan penelitian tentang morfologi dan struktur anatomi daun jambu air citra Demak yang banyak terserang hama, sehingga dapat membantu analisis dan diagnosis akibat serangan hama dan dapat membantu menentukan cara-cara pengendaliannya dalam upaya mencegah menurunnya produksi yang merugikan tanaman dan petani jambu.

\section{METODE PENELITIAN}

\section{Tempat dan Waktu}

Penelitian ini dilaksanakan pada bulan September 2013 - Januari 2014 di Laboratorium BSF Tumbuhan Fakultas Sains dan Matematika Universitas Diponegoro, Semarang.

\section{Bahan dan Alat}

Sampel daun jambu air Demak baik yang normal maupun yang terserang hama diperoleh dari Desa Kendaldoyong Demak, alkohol 70\%, xilol, pewarna safranin, dan canada balsam. Alat yang digunakan yakni pisau silet, kaca preparat dan kaca penutup, mikroskop, selotip, kutek,gunting, fotomikrograf dan kamera.

\section{Pengambilan Sampel dan Penyiapan Preparat}

Sampel daun Syzigium samarangensis yang normal dan yang terserang hama diambil lalu dipotong $2 \times 2 \mathrm{~cm}$ dan difiksasi dengan alkohol $70 \%$. Selanjutnya daun normal dan yang terserang hama dibuat preparat metode semipermanen dan untuk melihat hama yang melekat di daun dibuat metode replika (Botanika, 2008)

\section{Pembuatan Preparat Semi Permanen}

Sampel daun Syzigium samarangensis difiksasi dengan alkohol 70\%. Sampel daun kemudian diambil dan diiris setipis mungkin lalu ditaruh pada kaca preparat. Sampel daun yang telah diiris kemudian ditetesi dengan pewarna safranin $1 \%$ dalam alkohol $70 \%$ selama 5 menit.
Selanjutnya diganti xilol 1:3, 1:1, 3:1, dan xilol murni diteteskan secara berurutan masing-masing 3 menit. Selanjutnya ditetesi canada balsem kemudian ditutup perlahan dengan kaca penutup. Pengamatan dilakukan dibawah mikroskop dan difoto dengan fotomikrograf.

\section{Pembuatan Preparat dengan Metode Replika}

Permukaan sampel daun Syzigium samarangensis yang terkena hama diolesi dengan kutek dan didiamkan selama 5 menit hingga mengering. Dipotong selotip transparan lalu direkatkan pada sampel daun yang telah diolesi kutek tersebut kemudian diratakan. Potongan selotip kemudian dikelupas dari daun dan direkatkan pada kaca preparat dan diberi label. Pengamatan dilakukan dibawah mikroskop dan difoto dengan menggunakan fotomikrograf.

\section{HASIL DAN PEMBAHASAN}

Detail hasil pengamatan morfologi dan anatomi ditunjukkan pada tabel 1. Hasil pengamatan morfologi daun jambu air citra yang normal menunjukkan ciri-ciri bentuk bulat telur sampai lonjong atau elips dengan ujung meruncing, tepi rata, bertulang daun menyirip (Gambar 1). Lebar daun setengah dari panjangnya, warna hijau sampai hijau tua. Pengamatan secara mikroskopis menunjukkan daun tersusun oleh jaringan epidermis atas dan bawah, palisade parenkim, berkas pembuluh dan spons parenkim. Morfologi daun menunjukkan gejala berupa bercak warna coklat dengan bentuk tidak beraturan di permukaan atas dan bawah daun (Gambar 2). Hal ini merupakan gejala bahwa daun tersebut terserang hama pengorok daun Liriomyza spp. Pengamatan dibawah mikroskop menunjukkan bahwa sel-sel di bagian palisade parenkim di dekat epidermis atas terlepas, sehingga daerah tersebut menjadi renggang dan rusak (Katundu, 1980). Jaringan daun hanya menyisakan epidermis atas dan sebagian jaringan spons parenkim saja. Merenggangnya jaringan spons tersebut kemungkinan disebabkan karena bagian tersebut sebagian dimakan hama dan dijadikan sebagai jalan masuknya hama ke bagian jaringan yang lain pada daun. 
Tabel 1. Hasil Pengamatan Perbedaan Morfologi dan Anatomi Daun Syzigium samarangensis var Demak yang normal dan terserang hama perbesaran 10x10

No $\quad \begin{gathered}\text { Struktur Morfologi dan Anatomi } \\ \text { Daun Syzigium samarangensis }\end{gathered}$

Deskripsi Morfologi

Bentuk daunnya bulat telur sampai lonjong atau elips dengan ujung makin runcing. Lebar daun setengah dari panjangnya, warna hijau muda sampai tua.
Daun tersusun oleh jaringan epidermis atas dan bawah berkas pengangkut, spons parenkim dan palisade parenkim.

Gambar 1

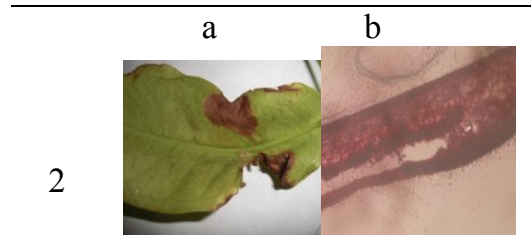

Gambar 2

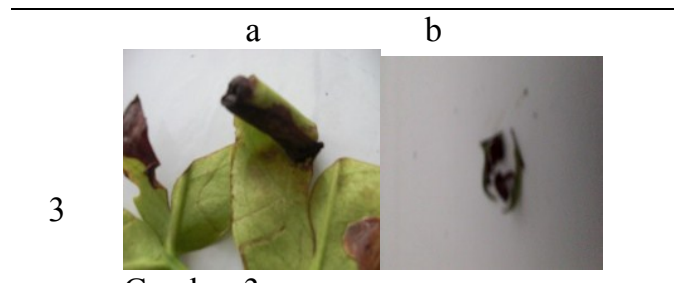

Gambar 3
Sel-sel palisade parenkim dekat epidermis atas terlepas/rusak, berwarna hitam. Daun hanya tinggal epidermis atas dan bawah, sebagian spons parenkim diserang ulat pengorok daun Liriomyza spp
Bagian helaian daun yang menggulung ujungnya berwarna coklat sampai hitam/ kehitaman dan menggulung ke dalam.
Irisan gulungan daun sel-sel epidermis atas dan spons parenkim rusak dimakan larva.Terdapat benang-benang sebagai penguat gulungan. Dalam gulungan terdapat telur - telur warna kuning. Daun akhirnya berwarna hitam dan hancur. Diserang ulat Sylepta spp
Sel-sel mesofil/palisade rusak dimakan oleh hama, baik dari permukaan atas, bawah daun atau melewati tulang daun sehingga menjadi habis. Bekas gigitan miring atau tegak lurus,vena berongga.Diserang ulat Acroceros syngramma

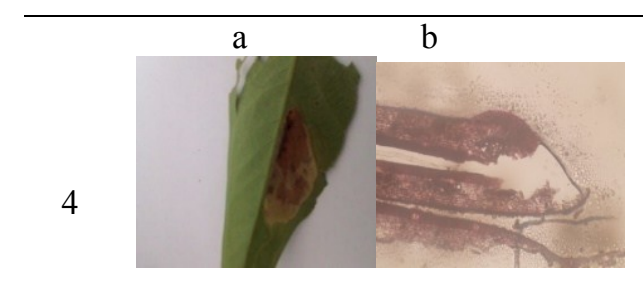
Helai daun tampak seperti menggelembung tetapi akhirnya mengempis dan berwarna gelap/coklat.

Gambar 4

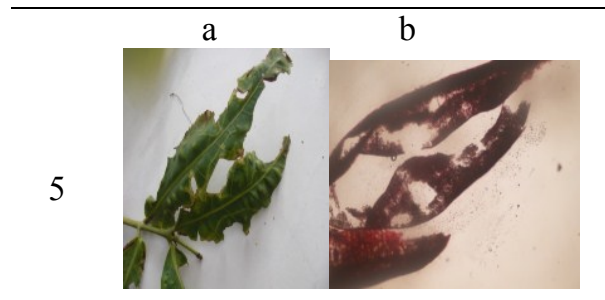

\begin{abstract}
Permukaan atas daun terdapat banyak bintil-bintil (membentuk gelembung), tepi daun tidak rata dan rusak
\end{abstract}

Sel-sel di daerah jaringan palisade dan spons rusak dikarenakan hama masuk pada daerah mesofil ,sehingga permukaan daun menonjol dan tidak rata. Diduga diserang ulat kipat Cricula trifenestrata $\mathrm{H}$

Gambar 5

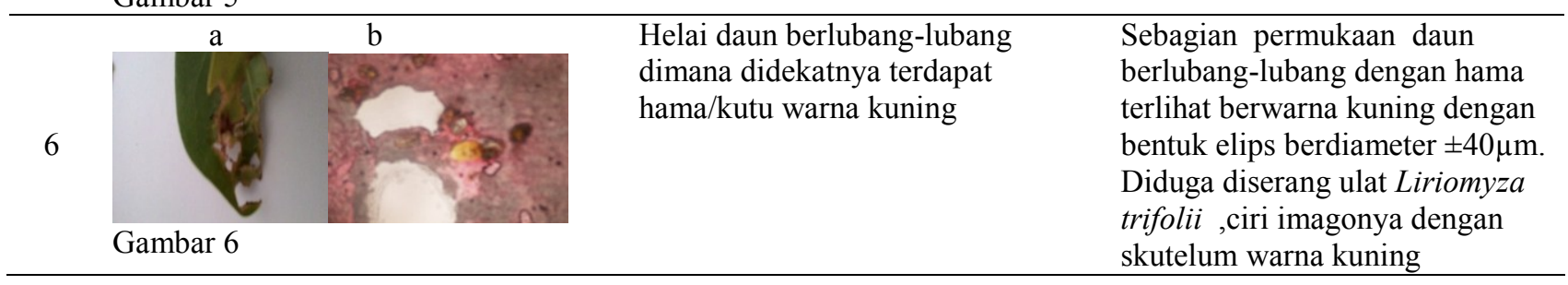


Pengamatan selanjutnya daun menunjukkan gejala berupa wana coklat hingga kehitaman pada bagian ujung daun yang menggulung ke dalam. Daun ini menunjukkan gejala diserang hama penggulung daun Sylepta spp yang temasuk ordo Lepidoptera. Serangan hama ini menyebabkan daun tersisa epidermis dan tulang-tulang serta urat-urat daunnya saja. Diantara gulungan daun terdapat benang-benang penguat dan gulungan yang paling ujung berwarna hitam. Jika dibuat irisan tipis bagian tepi yang menggulung berwarna hitam terlihat tinggal tulang daun saja (Gambar 3). Secara mikroskopis sel-sel bagian spons parenkim, palisade parenkim dan epidermis bawah membentuk gulungan, sehingga daerah tersebut menjadi kaku ,keropos dan lamalama rusak. Menurut Faekin (1992) larva memotong bagian tepi daun lalu daun digulung ke arah dalam dan membentuk tabung kecil. Di dalam gulungan tersebut larva memakan daun dan meletakkan telurnya. Telur diletakkan teratur dan rapi pada pinggiran daun sebelah bawah dalam jumlah banyak.

Kerusakan serupa selanjutnya adalah terlihatnya lubang-lubang dalam daun yang disebabkan olah larva. Serangan parah menyebabkan helai daun berwarna merah kecoklatan. Diduga tanda ini adalah serangan hama pengorok daun yang lain yaitu disebabkan Acrocercops syngramma Meirick. Menurut Deptan (1995), spesies ini dikenal sebagai ulat pengorok daun yang polifag dan lebih menyukai daun yang muda. Ulat ini menyerang saat tumbuhan jambu fase vegetatif. Akibat serangan ulat ini akan terjadi liang yang berliku-liku pada daun yang dimakan (Gambar 4). Bekas tusukan yang dimakan dan peletakan telur terlihat berupa bintik-bintik putih. Ulat akan membuat lubang keluar pada epidermis daun dan selanjutnya memakan jaringan mesofil, sehingga lapisan epidermis lama-lama mengelupas. Bila hal ini terjadi maka ulat akan keluar dari rongga dan akan membuat rongga baru. Selanjutnya bagian daun yang dimakan akan mengering dan gugur. Ulat yang baru menetas berwarna putih, segera mengorok di antara epidermis bagian atas dan bawah. Ulat-ulat yang muda berdiam dalam daun-daun muda, sehingga daun tampak bengkok-bengkok. Ulat-ulat yang dewasa akirnya menjatuhkan diri ke tanah untuk memasuki masa pupa.

Pengamatan morfologi daun jambu yang berupa helai daun dengan bekas warna coklat gelap menunjukkan gejala terserang ulat kipat Cricula trifenestrata $\mathrm{H}$. Ulat ini termasuk ordo Lepidoptera memiliki tipe mulut menggigit dan akan mengunyah mesofil daun,sehingga daun tidak dapat untuk fotosintesis. Stadia ulat paling efektif menyerang dan merusak daun tua dan muda sampai habis. Keadaan ini dapat menghambat fase pembungaan tanaman, sehingga dapat menurunkan produksi buah jambu (Soebandrijo et al, 1994). Pengamatan daun secara anatomis menunjukkan jaringan epidermis atas dan bawah, spons parenkim dan tulang daun dimakan habis, tinggal menyisakan bekas gigitan (Gambar 5). Pengamatan daun yang terserang hama berikutnya adalah permukaan daun terdapat tonjolan-tonjolan atau bintil-binti, sehingga helai daun menjadi tidak rata/keriput.

Pengamatan berikutnya adalah morfologi daun yang terserang hama menjadi berlubanglubang. Secara mikroskopis daun tersebut menunjukkan sel-sel epidermis dan jaringan spons dan palisade rusak serta berkas pengangkut hilang,sehingga membentuk rongga-rongga. Hal ini menunjukkan bahwa bekas lubang tersebut diduga telah dimakan hama ulat pengorok daun yang lain Liriomyza trifolii. Diduga imago hama ini dengan punggung warna kuning di dekat lubang daun sebagai pemakan daun tersebut (Gambar 6). Hama dengan kepala hitam sedang memakan daun.

\section{SIMPULAN}

1. Secara morfologi daun yang normal dan terserang hama berbeda. Daun yang normal/sehat benbentuk lonjong, sedang yang terserang hama tepi daun tidak rata, helaian berlobang, permukaan ada tonjolan-tonjolan atau terkelupas. Warna helai daun coklat atau hitam

2. Secara anatomi /mikroskopis daun normal/sehat tersusun oleh jaringan epidermis bawah dan atas, palisade dan spons parenkim 
serta berkas pembuluh, sedang daun yang terserang hama ada yang palisade parenkimnya rusak, mesofil daun beronga-rongga, tepi daunnya tidak rata, permukaan helai daun berbintil-bintil atau helai daun berlubang akibat dari sel-sel yang rusak atau dimakan hama.

\section{DAFTAR PUSTAKA}

Adieb, S. 2011. Jambu Delima dan Jambu Citra. http://citradelima.blogspot.com/.Diakses 25 Januari 2014

Anonymous, 2011. Petunjuk Teknis Pengendalian Ulat Bulu. Jakarta : Badan Litbanga Pertanian, Kementerian Pertanian RI

Botanika, 2008. Beberapa Medode pembuatan preparat Tumbuhan. http://maximillioncortes.blogspot.com. Diakses 11 Januari 2014

Departemen Pertanian. 1995. Pengenalan dan Identifikasi Hama penyakit tanaman Jambu Mete. Jakarta : Bina perlindungan Tanaman

Djafarudin. 2001. Dasar-dasar Perlindung Tanaman (Umum). Jakarta : Bumi Aksara

Feakin, S.D. 1991. Pest Control in Bananas Pans Manual. London. : Centre of Overseas Pests Research.

Hariyanto, B. 1992. Jambu Air. Jakarta. Penebar Swadaya

Katundu, J. M. 1980. Agromyzid Leafminer : a new insect pest to Tanzania Trop. Grain Legume Bull

Prihatman, K. 2000. Bertanam Jambu Air. Jakarta: Trubus

Rauf, A. 1995. Liriomyza; Hama Pendatang Baru di Indonesia. Jakarta : Buletin Hama dan Penyakit Tumbuhan

Setjo, S. 2001. Anatomi Tumbuhan. Malang : Universitas Negri Malang Press

Soebandrijo, Nurindah, I.G.G.A Indrayani, A. M. Amir. 1994. Pengendalian Serangga
Hama Kapas di Indonesia. Jurnal Penelitian dan Pengembangan Pertanian Tarumangkeng, R.C. 1994. Dinamika Populasi Kajian Ekologi Kuantitatif

Triharso. 2004. Dasar-dasar Perlindungan Tanaman. Yogyakarta : Gadjah Mada University Press. 